\title{
Trace metal partitioning and potential mobility in the naturally acidic sediment of Lake Caviahue, Neuquén, Argentina
}

\author{
*Juan Manuel Cabrera', Pedro Félix Temporetti ${ }^{1}$ Fernando Luis Pedrozo ${ }^{1}$
}

\author{
I GECARA, INIBIOMA-CONICET-Universidad Nacional del Comahue, Quintral 1250, Bariloche, Argentina. \\ correocabrera@gmail.com; temporettipf@comahue-conicet.gob.ar; pedrozofl@comahue-conicet.gob.ar
}

* Corresponding author: correocabrera@gmail.com

\begin{abstract}
Lake Caviahue, in Patagonia (Argentina), is a very acid water body (Patagonia, Argentina) due to the influx of volcanic fluids. Over the past 18 years, the lake has been progressively alkalinizing and $\mathrm{pH}$ is close to the ferric iron precipitation threshold $(\mathrm{pH}>3,0)$. Should iron precipitate, water and sediment composition will be altered. To set a baseline, trace metal partitioning $(\mathrm{Cu}, \mathrm{Cd}, \mathrm{Cr}, \mathrm{Pb}, \mathrm{Zn}$ and $\mathrm{Mn})$ was studied for three sediment cores $(0$ to $16 \mathrm{~cm}$ depth) at three sampling stations using a sequential extraction procedure (SEP) and the acid volatile sulfide/simultaneously extracted

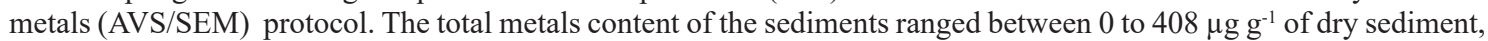
with $\mathrm{Pb}>\mathrm{Cr}>\mathrm{Mn}>\mathrm{Cu}>\mathrm{Zn}>\mathrm{Cd}$. No Cd was measured above the limit of detection. The sediment was richest in $\mathrm{Mn}$ and $\mathrm{Cr}$, two non-toxic metals at the $\mathrm{pH} / \mathrm{Eh}$ combination of the lake basin. Total $\mathrm{Pb}$ was at a moderate contamination level although it is associated with the most recalcitrant fraction and therefore has low mobility. The sediment fractions with higher metal content were the oxidizable and residual, the former commonly associated with labile organic matter and pyrite while the latter are related to recalcitrant organic matter and rock forming minerals. In addition, a high correlation was found between $\mathrm{Cr}, \mathrm{Pb}$ and $\mathrm{Mn}$, thus these metals may be subject to analogous precipitation processes and possibly to co-variation in the volcano effluents. Furthermore, no metals were detected in the exchangeable/carbonates fraction, which is the most labile of all the sediment fractions. The metal content in (SEM) was likewise below the toxicity thresholds of two international sediment quality guidelines and the ratio AVS/SEM was over one, indicative of non-toxicity. Both results indicate that metal mobility in the acidic sediments of lake Caviahue is very low.
\end{abstract}

Keywords: Naturally acid sediments, Trace metal partitioning, Metal mobility, Sediment toxicity.

RESUMEN. Fraccionamiento y mobilidad potencial de metales traza en el sedimento ácido natural del Lago Caviahue, Neuquén, Argentina. El Lago Caviahue es un cuerpo de agua extremadamente ácido ubicado en el norte de la Patagonia Argentina. La acidez se debe a que la naciente de uno de sus afluentes principales se encuentra en un manantial de efluentes del volcán Copahue. Durante los últimos 18 años, el pH del lago a aumentado progresivamente hasta hallarse cerca del umbral de precipitación del ion férrico $(\mathrm{pH}>3,0)$. Si el hierro precipitara, la composición del agua y del sedimento cambiaría. Para determinar una línea de base previa a este cambio, se realizó un estudio del fraccionamiento de metales traza $(\mathrm{Cu}, \mathrm{Cd}, \mathrm{Cr}, \mathrm{Pb}, \mathrm{Zn}$ y $\mathrm{Mn}$ ) en tres testigos de sedimentos (de 0 a $16 \mathrm{~cm}$ de profundidad en el sedimento) en tres sitios representativos del lago. Para ello se utilizaron un método de extracción secuencial (SEP) y el protocolo de extracción de sulfuros ácidos volátiles y metales simultáneamente extraídos (AVS/SEM). El contenido total de los metales estudiados en los sedimentos osciló entre 0 y $408 \mu \mathrm{g} \mathrm{g}^{-1}$ de sedimento seco, con $\mathrm{Pb}>\mathrm{Cr}>\mathrm{Mn}>\mathrm{Cu}>\mathrm{Zn}>\mathrm{Cd}$. El cadmio se halló siempre por debajo del límite de detección. Dos de los metales más abundantes, Cr y Mn no son tóxicos en la combinación de $\mathrm{pH}$ / Eh determinadas en el sedimento de la cuenca. Se determinó que los niveles de $\mathrm{Pb}$ hallados se corresponden con un nivel de contaminación moderado, aunque este se halla mayormente asociado a la fracción más recalcitrante del sedimento y por lo tanto su movilidad potencial es baja. Las fracciones de sedimento con mayor contenido de metales fueron la oxidable y la residual, la primera comúnmente asociada con materia orgánica lábil y pirita, mientras que la segunda con materia orgánica recalcitrante y con minerales formadores de rocas. Además, se halló una fuerte correlación entre $\mathrm{Cr}, \mathrm{Pb}$ y $\mathrm{Mn}$, por lo que estos metales pueden estar sujetos a procesos de precipitación 
análogos y posiblemente su contenido en los efluentes volcánicos varíe en la misma proporción. No se detectaron metales asociados a la fracción intercambiable/carbonatos que son las más lábiles del sedimento. Sumado a ello, el contenido de metales hallados en la fracción SEM estuvo en todos los casos por debajo del umbral de toxicidad de dos niveles guía internacionales para sedimentos de cuerpos de agua dulce. En este sentido, el indicador de toxicidad calculado como AVS/SEM no arrojó indicios de toxicidad para ninguno de los sitios y estratos evaluados. Estos últimos resultados indican que la movilidad potencial de los metales estudiados en el sedimento ácido del Lago caviahue es muy baja.

Palabras clave: Sedimentos naturalmente ácidos, Fraccionamiento de metales traza, Movilidad de metales, Toxicidad del sedimento.

\section{Introduction}

The effects of anthropogenically induced acidification of surface water bodies have been extensively studied (Dillon et al., 1984; Geller et al., 1998). In recent years highly acidic lakes and rivers of natural origin were thoroughly studied to better understand nutrient dynamics, limnology and hydrochemistry (Pedrozo et al., 2001; Wendt-Potthoff and Koschorreck, 2002; Pedrozo et al., 2008a; Varekamp, 2008; Cabrera et al., 2016; among many others).

Surface waters may become extremely acid due to the influence of acid mine drainage (AMD), volcanic activity and/or natural weathering of pyrite. In these kind of processes, the contribution of acid rain or organic acids runoff are negligible. Final $\mathrm{pH}$ in strongly acidic water bodies is below 4.0 (Geller et al.,1998; Löhr et al., 2006), creating high concentrations of iron and aluminum in such waters (Stumm and Morgan, 1996; Geller et al., 1998). In addition, potentially toxic concentrations of trace elements such as copper, lead, chromium, zinc and cadmium are found (Gammons et al., 2005; Pedrozo et al., 2008a; Varekamp, 2008).

Lake Caviahue, the subject of the present study, is very acid, deep, oligotrophic with low planktonic diversity and is unique in South America (Pedrozo et al., 2001; Pedrozo et al., 2008a). Located in the north Patagonian Andean Mountains (Fig. 1), the special characteristics that differentiate it from the

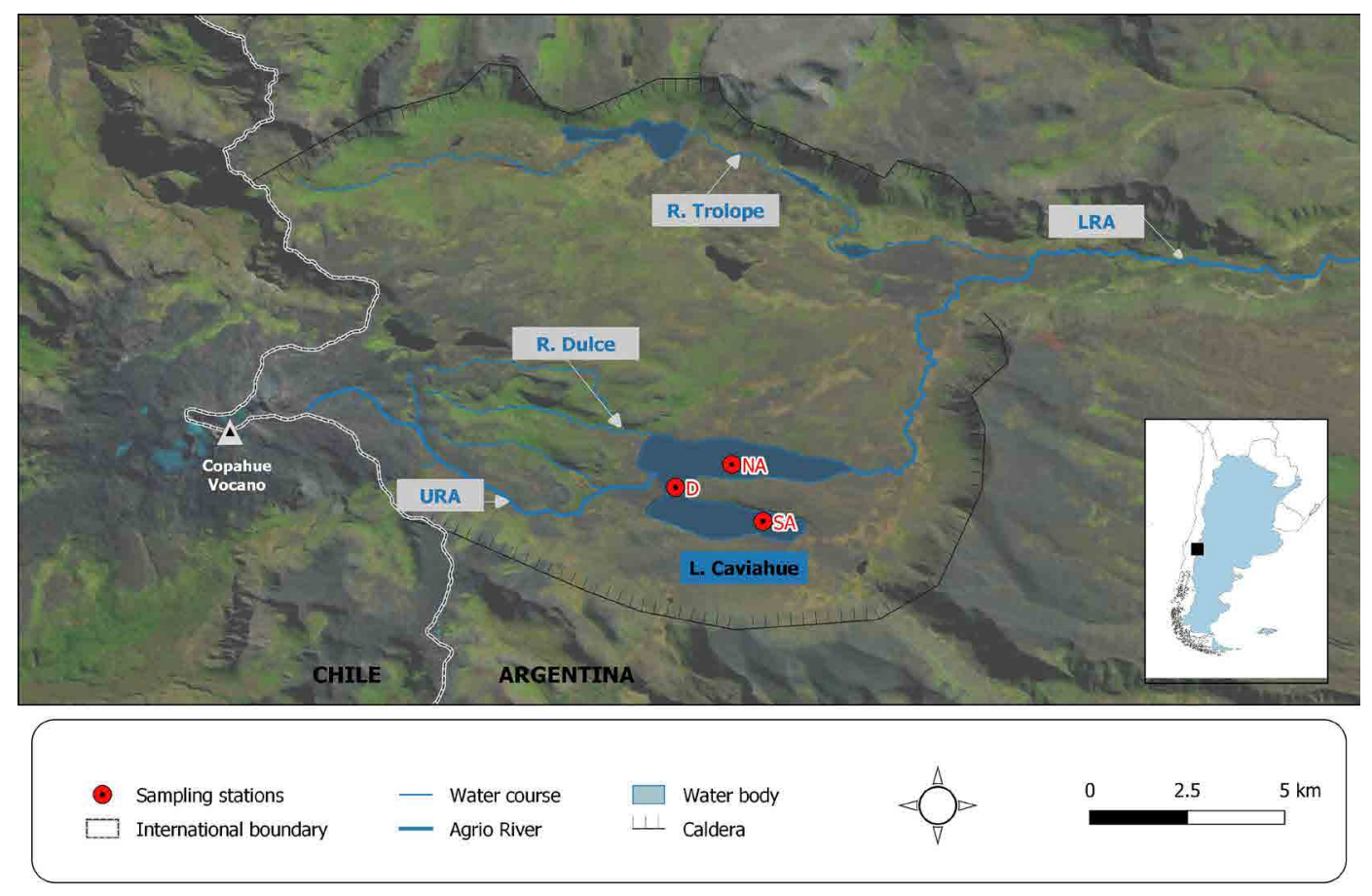

FIG. 1. Copahue Volcano, Caviahue Lake, upper río Agrio (URA), lower río Agrio (LRA), Ríos Dulce and Trolope. Sampling stations at NA, SA and at URA delta (D). 
other lakes of the region are primarily due to the activity of the Copahue Volcano (Delpino et al., 1997; Diaz et al., 2007; Varekamp, 2008).

Extractable heavy metals in lake sediments are often found in association with chemical phases such as exchangeable (adsorbed) heavy metals, carbonates, Fe oxides, $\mathrm{Al}$ and $\mathrm{Mn}$ oxides, monosulfides $(\mathrm{MeS})$, pyrite $\left(\mathrm{FeS}_{2}\right)$ and organic matter $(\mathrm{OM})$. Organic matter related metals are often found in tissue or cell walls of living organisms, detritus, soluble humic substances (HS) with low molecular weight as well as in HS coatings on mineral particles (Tessier et al., 1979). The association of metals in lake sediments is governed by local conditions such as $\mathrm{pH}$ and redox potential (Eh; Butler and Rickard, 2000). For example, trace metals mainly co-precipitate with Fe-Mn oxides in oxic sediments while precipitation is related to metal sulfides and pyrite under anoxic conditions. At both Eh ranges carbonates and OM may also be conspicuous metal scavengers.

The most labile fractions considered elsewhere are: exchangeable, monosulfides and carbonates (Allen et al., 1991, 1993; Perin et al., 1985) and thus, the most readily available metal is commonly related to them. Many sediment toxicity indexes are based on the concentration of these fractions, such as the Acid Volatile Sulfide (AVS) to Simultaneously Extracted Metals (SEM) ratio (AVS/SEM ratio) (Allen et al., 1993) or the percentage of heavy metals in the exchangeable/carbonates fraction (Perin et al., 1985). Moreover, international sediment quality guidelines devised by the Canadian Council of Ministers of the Environment (CCME, 2001) or the Australian and New Zeland Conservation Council (ANZECC, 2000) are often used as contamination level indicators. Hübner et al. (2009) suggested that these guidelines are composed considering parameters such as local background concentration and should be carefully employed outside their original area of application.

Metal partitioning studies are often performed on acidic sediments from acid mine drainage (AMD). Examples are the Iberian Pyrite Belt, the Mining Lakes District in Germany or massive sulfide deposits in the Yukon Territory, Canada (Geller et al., 1998; Friese et al., 1998; Kwong and Lawrence, 1998; Bachmann et al., 2001; Torres and Auleda, 2013). Moreover, investigations of sediments of naturally acid water bodies mainly analyze total metal content and mineralogy rather than chemical partitioning.
Objectives of the present study are to analyze the partitioning of $\mathrm{Mn}, \mathrm{Pb}, \mathrm{Cr}, \mathrm{Cu}, \mathrm{Zn}, \mathrm{Cd}$ in the highly acidic sediments of Lake Caviahue, to study the potential mobility of the metals and to create the first baseline record of an extremely acid lake. Our findings will allow to predict new scenarios in metal cycling if the $\mathrm{pH}$ of lake Caviahue continues to rise.

\section{Study Area}

Lake Caviahue is located in the Copahue-Caviahue Provincial Park $\left(37^{\circ} 53^{\prime} \mathrm{S} ; 7^{\circ} 02^{\prime} \mathrm{W}\right)$, Neuquén, Argentina, at 1,600 m a.s.l. (Fig. 1). Located on the west side of the northern arm is the town of Caviahue, with almost 1,000 inhabitants and a variable number of incoming tourists that visit Copahue thermal bath complex and Caviahue ski resort both located on the volcano slope. The lake is a glacial water body with a maximum length of $9.7 \mathrm{~km}$, maximum width of $4.7 \mathrm{~km}$, coastline of $22.3 \mathrm{~km}$, total area of $9.2 \mathrm{~km}^{2}$ and total volume of $0.47 \mathrm{~km}^{3}$. The water residence time has been calculated by Varekamp $(2003,2008)$ to be 42-48 months based on conservative element fluxes $(\mathrm{Mg}, \mathrm{Cl})$ in and out of the lake. Lake Caviahue has a horseshoe shape with two basins, northern and southern with a depth of $90 \mathrm{~m}$ and $70 \mathrm{~m}$, respectively. It has two major influxes: the río Dulce (average flow of $1.23 \mathrm{~m}^{3} \mathrm{~s}^{-1}$ ) and the upper río Agrio (URA, average flow of $1.10 \mathrm{~m}^{3} \mathrm{~s}^{-1}$ ). The former is a scrubby forested, soil-covered basin with a $\mathrm{pH}$ of 6.5 while the latter is born on the east slope of the Copahue Volcano (Pedrozo et al., 2001) and has an initial $\mathrm{pH}$ $<1.0$, temperature of $82^{\circ} \mathrm{C}$, conductivity of $560 \mathrm{mS}$ $\mathrm{cm}^{-1}$ and flows into the lake with a $\mathrm{pH}$ of 0.8 to 2.5. The río Dulce discharge into the northern arm, the URA joins the lake close to the union of the arms (Delta, Fig. 1). Lake Caviahue $\mathrm{pH}$ has been rising from 2.2 to 3.4 over the last 18 years (Pedrozo et al., 2008a; Varekamp, 2008; Cabrera et al., 2016). In addition, it has high electric conductivity (560 to $1600 \mu \mathrm{S} \mathrm{cm}^{-1}$ ) and high concentrations of $\mathrm{PO}_{4}^{-3}, \mathrm{Fe}, \mathrm{Al}$, $\mathrm{Mn}, \mathrm{Cl}, \mathrm{F}, \mathrm{Si} \mathrm{S}, \mathrm{Na}, \mathrm{K}, \mathrm{Ca}$ and trace metals (Pedrozo et al., 2001; Pedrozo et al., 2008a; Varekamp, 2008; Cabrera et al., 2016). Because of these characteristics, Lake Caviahue is unique amongst Andean lakes, which are usually circumneutral and oligotrophic (Diaz et al., 2007).

The lower río Agrio (LRA) exits Lake Caviahue with a $\mathrm{pH}$ near 3.0 and joins the río Neuquén approximately $200 \mathrm{~km}$ downstream with a $\mathrm{pH}$ of 8.0 
due to the contribution of several dilute tributaries (Baffico et al., 2004).

Andesite and basaltic andesite are the predominant rock types of the basin (Pesce, 1989; Varekamp et al., 2008; Varekamp, 2015) the latter from the year 2000 eruption of the volcano. The average content of organic matter in the lake sediments is $9.5 \%$. The sediment is also rich in phosphorus (average $1.1 \mathrm{mg} \mathrm{g}^{-1}$ in association with the organic fraction). The sediments average electric potential (Eh) is $-120 \mathrm{mV}(-20 /-180 \mathrm{mV})$, and the $\mathrm{pH}$ ranges between 3.0 and 4.0 for both arms of the lake, and between 3.0 and 6.0 at the delta near the mouth of the URA (Temporetti et al., 2013; Cabrera et al., 2016).

The sediments of the deep areas of the basin are covered by a benthic biofilm (Fig. 2) composed mainly by Keratococcus rhaphidioides, bacteria and yeast. The same algal species is also the most abundant $(>90 \%)$ of the lake phytoplakton (Beamud et al., 2010) and the cell walls are coated with adsorbed Fe and $\mathrm{P}$ in similar ratios to those found in the sediments (Cabrera et al., 2016 and data not shown).

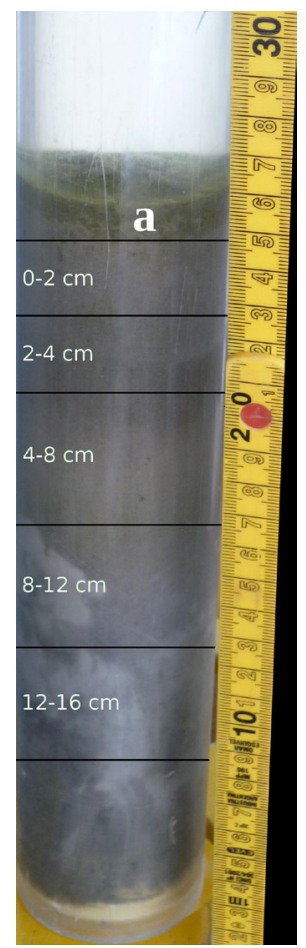

FIG. 2. Sediment core from SA sampling station. The letter "a" corresponds with the green benthic biofilm due to K. rhaphidioides.

\section{Materials and methods}

\subsection{Sample collection, processing and in situ measurements}

Three sediment cores were obtained with a $6 \mathrm{~cm}$ diameter, Uwitec-type corer in January of 2013. Sampling was performed at three sites: northern arm (NA; 90 m depth), southern arm (SA; $70 \mathrm{~m}$ depth), and at the URA delta (D; $20 \mathrm{~m}$ depth) (Fig. 1). Cores were sliced into five strata of $2 \mathrm{~cm}$ thick in the upper horizon $(0$ to $4 \mathrm{~cm}$ ) and $4 \mathrm{~cm}$ thick thereafter ( 4 to $16 \mathrm{~cm}$ ), registering $\mathrm{pH}$ and $\mathrm{Eh}$ (Orion 920A) of the pore water from each stratum. Samples were then stored in polyethylene bags under $\mathrm{N}_{2}$ atmosphere at $4{ }^{\circ} \mathrm{C}$ for no longer than $24 \mathrm{~h}$ before being frozen. All analyses were performed within one week.

In the laboratory, fresh sediment samples were carefully homogenized by hand inside the bag (under $\mathrm{N}_{2}$ atmosphere). Aliquots of approximately $3 \mathrm{~g}$ (equivalent to $1 \mathrm{~g}$ of dry sediment, $\mathrm{dw}$ ) of each fresh sample was put into polypropylene and glass tubes for metal extraction. All reagents were of analytical grade and deionized water was used. Oxygen in the reagents was removed by $\mathrm{N}_{2}$ bubbling before use. The extraction procedures were completed before $48 \mathrm{~h}$ after sub-sampling.

\subsection{Chemical analysis}

Metal partitioning was analyzed by two methods: 1) Sequential extraction procedure (SEP) proposed by Tessier et al. (1979) and 2) Acid Volatile SulfidesSimultaneously Extracted Metals (AVS-SEM) method proposed by Allen et al. (1991, 1993). Both protocols were performed on three replicates of fresh anoxic sediments under nitrogen atmosphere in order to preserve the metal distribution among the Sediment components. SEP steps were as follows:

1. Ten milliliters of $1.0 \mathrm{M} \mathrm{NaOAc}$ (adjusted to $\mathrm{pH}=5.0$ with acetic acid) were added to a fresh aliquot of sediment from each stratum (equivalent to approximately $1 \mathrm{~g}$ of dry sediment). The first step was eliminated because, based on previous determinations, all the trace metals studied were below the limit of detection in the pore water and $\mathrm{MgCl}_{2}$ extracts. In addition, carbonates are not a conspicuous phase at the sediment $\mathrm{pH}$. In consequence, this step will be referred to as exchangeable and/or F1. 
2. Twenty milliliters of $0.5 \mathrm{M}$ Hydroxylamine $\cdot \mathrm{HCl}$ were added to the residue of step 1) and the mixture was heated to $96^{\circ} \mathrm{C}$ for five hours, softly agitated every 15 minutes. This step dissolves elements bound to Fe-Mn oxides and will be referred to as reducible and/or F2.

3. The residue of step 2) was treated with $5.0 \mathrm{~mL}$ of 8.8M Hydrogen peroxide adjusted to $\mathrm{pH} 2.0$ with $\mathrm{HNO}_{3}$ and the mixture heated to $85{ }^{\circ} \mathrm{C}$ for $2 \mathrm{~h}$. At that time, an extra aliquot of solvent of $3.0 \mathrm{~mL}$ was added and heated to the same temperature for three more hours. In both steps reaction vessels were agitated every 20 minutes. At the end time, $5.0 \mathrm{~mL}$ of $3.2 \mathrm{M} \mathrm{NH} 4 \mathrm{OAc}$ in $20 \% \mathrm{HNO}_{3}$ were added, the mixture was diluted to $20 \mathrm{~mL}$ and agitated again for 30 minutes. With concentrated $\mathrm{H}_{2} \mathrm{O}_{2}$ labile $\mathrm{OM}$, pyrite and the remaining sulfides are extracted. This step will be referred to as oxidizable and/or F3.

4. The residue of step 3) was digested with $12 \mathrm{~mL}$ of $\mathrm{H}_{2} \mathrm{SO}_{4}: \mathrm{H}_{2} \mathrm{O}_{2}(1: 1)$ mixture heated to $450{ }^{\circ} \mathrm{C}$ (Carter, 1993). This is a pseudo-total extraction that will partially attack the minerals of rocks such as andesite or basaltic andesite, although the hot acid will attack and partially dissolve volcanic glasses, plagioclase, feldespar, piroxene and amphibole. Tessier et al. (1979) and others saw that recalcitrant $\mathrm{OM}$ is not completely oxidized with F3) and the metals in potential association with that fraction were of interest in this work. This step will be referred to as residual and/or F4. Acid volatile sulfides (AVS) and the simultaneously extracted metals [SEM] content were analyzed following the cold-acid purge-and-trap method as done in Allen et al. (1993). Briefly, aliquots of $3 \mathrm{~g}$ of fresh sediments were put in glass containers (as described above). The extraction apparatus consisted of a $\mathrm{N}_{2}$ gas tube connected in series with the sample container and two polypropylene tubes with $1.0 \mathrm{M} \mathrm{NaOH}$ solutions. Samples were purged with $\mathrm{N}_{2}$ for ten minutes to remove $\mathrm{H}_{2} \mathrm{~S}$ with a flow of $40 \mathrm{~mL} \mathrm{~min}^{-1}$. The gas flow was stopped while $10 \mathrm{~mL}$ of $1.0 \mathrm{M} \mathrm{HCl}$ was being introduced with a $20 \mathrm{~mL}$, stainless steel needle, glass syringe. The cold acid reacts with the metal sulfides of the sediments to form volatile $\mathrm{H}_{2} \mathrm{~S}$ and dissolved metal chlorides. This hydrogen sulfide (AVS) was carried by the $\mathrm{N}_{2}$ flow and trapped in the $1.0 \mathrm{M} \mathrm{NaOH}$ solutions. The acid solution containing the metal chlorides [SEM] was filtered by $0.2 \mu \mathrm{m}$ acetate membranes from the acid/sediment mixture and stored at $4{ }^{\circ} \mathrm{C}$ until metal content was quantified. The concentration of sulfides in the $1.0 \mathrm{~m} \mathrm{NaOH}$ solutions was determined by the iodometric method (APHA, 1992). The percent recovery was estimated at $90.1 \pm 5.1 \%$ after the analysis of six replicates of $\mathrm{Na}_{2} \mathrm{~S}$ solutions. Allen et al. (1993) calculated the ratio AVS to SEM and defined it as an indicator of contamination when the value is of 1.0 or lower, meaning the content of metals leachable with cold acid was higher than the content of metal sulfides.

The sequential extraction procedure was employed to describe metal partitioning amongst the sediment facies and will yield information about how labile or recalcitrant the studied trace metals are. The second extraction was used to assess the content of metal sulfides and to calculate the risk indicator described above. Both methods complement each other and allow a broader description of the sediments.

The concentration of metals in the extractants was determined by atomic absorption spectrometry (FAAS, PE Analyst 100) with deuterium background correction and quantified with matrix-matched standards. The limit of detection (LOD) varied between metals, being $0.10 \mu \mathrm{g} \mathrm{d} \mathrm{dw}^{-1}$ for $\mathrm{Zn}$, $0.9 \mu \mathrm{g} \mathrm{g} \mathrm{dw}^{-1}$ for $\mathrm{Cu}, 5.0 \mu \mathrm{g} \mathrm{dw}^{-1}$ for $\mathrm{Pb}, 0.5 \mu \mathrm{g} \mathrm{g}$ $\mathrm{dw}^{-1}$ for $\mathrm{Cd}, 4.0 \mu \mathrm{g} \mathrm{g} \mathrm{dw}{ }^{-1}$ for $\mathrm{Cr}$ and $0.9 \mu \mathrm{g} \mathrm{dw}^{-1}$ for $\mathrm{Mn}$ in accordance with the mass of sediment and volume of extractant employed in the extractions. Iron and humic acid concentration in the sediments was taken from the dataset of Cabrera et al. (2016).

\subsection{Statistical analysis}

Due to the lack of homogeneity of variances, Kruskal Wallis (KW) test was used to search for significant differences in metal concentrations among sites and strata. The degree of correlation between the studied variables was determined using a Pearsons correlation test. The level of significance was fixed at $\alpha=0.05$ and Infostat 2017 software was used to perform all analyses.

\section{Results}

\subsection{Sediment characterization}

The textural characteristics of Lake Caviahue sediment cores were described in Temporetti et al. (2013). These authors found that the sediment 
cores in NA y SA sampling stations were dominated mainly by medium to coarse texture fractions (20 to $250 \mu \mathrm{m}$ ), the clay fraction in both sites represented $<5 \%$ of the total while the silt and fine sand fractions predominated in all groups, representing between 10 and $20 \%$ of the total. In this sense, the sediments of the Lake were classified as sandy-loam. Moreover, the element abundance in sediments determined with EDS was $\mathrm{Si}>>\mathrm{Al}>\mathrm{S}>\mathrm{Na}>\mathrm{Fe}>\mathrm{P}>\mathrm{Ca}>\mathrm{K}>\mathrm{Mg}$ in both arms with minor differences in composition ratios. Expressed as oxides, the most abundant was $\mathrm{SiO}_{2}$ with an average $73 \%$ in all layers, $\mathrm{Al}_{2} \mathrm{O}_{3}$ ranged between $11 \%$ and $12 \%$ while $\mathrm{SO}_{3}$ accounted for $3.4 \%$ to $6.1 \%$ of the total oxides (Temporetti et al., 2013). Likewise, these authors analyzed the mineralogy of lake sediments and found that the predominant minerals were: Andesine $\left((\mathrm{Na}, \mathrm{Ca})(\mathrm{Si}, \mathrm{Al})_{4} \mathrm{O}_{8}\right)$, Albite $\left(\mathrm{Na} \mathrm{AlSi} \mathrm{O}_{8}\right)$, Anorthite $\left(\mathrm{CaAl}_{2} \mathrm{Si}_{2} \mathrm{O}_{8}\right)$ and Cristobalite $\left(\mathrm{SiO}_{2}\right)$, indicating that the sediments are of volcanic origin supplied mainly by the URA and reflect the volcanic features of the basin.

In figure 2, the photograph of a sediment core from SA sampling station is shown. The letter "a" marks the benthic biofilm green layer on the sediment surface. The basaltic andesite and volcanic ash derived main components of the sediment, decomposing $\mathrm{OM}$ and to some extent iron sulfides such as pyrite are responsible for the grey color. In addition, no red/orange oxidized iron species can be seen in the vertical profile of the core.

$\mathrm{Eh}, \mathrm{pH}$ and $\mathrm{OM}$ content in the sediments was presented in Cabrera et al. (2016). Briefly, interstitial water $\mathrm{pH}$ rose towards the lower strata (3.0 to 4.0) at a similar rate for both NA and SA sampling stations. At $\mathrm{D}$ the same trend was observed but final $\mathrm{pH}$ was 6.0 (Fig. 3A). Eh also becomes more negative downwards at all three sites. Measurements on sediments from sampling station D yielded less negative values from 0 to $12 \mathrm{~cm}$ although it drops to values ca.-100 $\mathrm{mv}$ at the bottom stratum (Fig. 3A). Eh for the water column above the sediments was $+680 \mathrm{mV}$ and average $\mathrm{pH}$ 2.9.

Organic matter (OM) content varied from 5 to $13 \%$ on average (Fig. 3B). Humic acid (HA) ranged from 0.5 to $3.5 \%$ and no correlation was observed with total OM. While total HA at NA sampling station dropped by $75 \%$ between upper and lower strata $(2.2$ to $0.5 \%$ average content, Fig. $3 \mathrm{C}$ ), total $\mathrm{OM}$ fell by only $50 \%$ (10 to $5 \%)$. Organic matter had the same profile at SA sampling station though with higher values while HA concentration increased from 2.5 to $3.5 \%$ before it finally dropped to $1.5 \%$ (Fig. 3B). Lastly, at D sampling station organic matter rose from 7.5 to $11 \%$ as HA dropped from 1 to $0.5 \%$.

\subsection{Trace metal partitioning by SEP}

Overall trace metal content analyzed by SEP was: $\mathrm{Pb}>\mathrm{Cr}>\mathrm{Mn}>\mathrm{Cu}>\mathrm{Zn}>\mathrm{Cd}$.

\subsubsection{Manganese}

Eighty nine percent of Mn was found significantly associated with the F4 residual fraction $(p<0.0001)$. Its total content (expressed as the sum of all fractions) ranged between $43-87 \mu \mathrm{g} \mathrm{g}^{-1}$ at NA sampling station, 24-40 $\mu \mathrm{g} \mathrm{g}^{-1}$ at D sampling station and $40-74 \mu \mathrm{g} \mathrm{g}^{-1}$ at SA sampling station (Fig. 4A-C). The reducible (F2) and oxidizable (F3) fractions were significantly
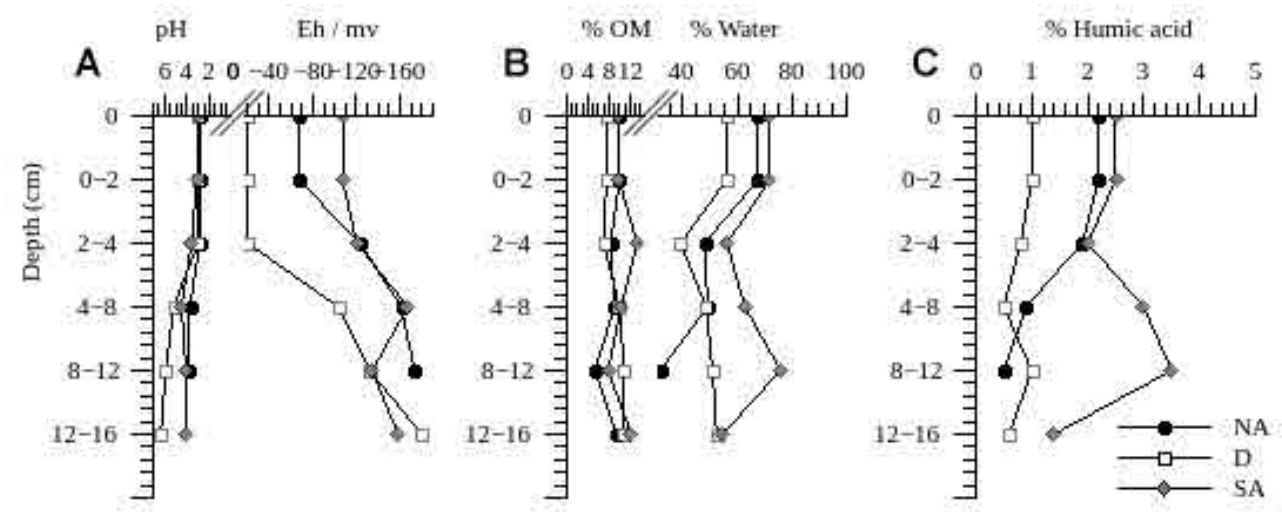

FIG 3. pH, Eh, OM, Water and humidic acid (HA) content (from Cabrera et al., 2016) 

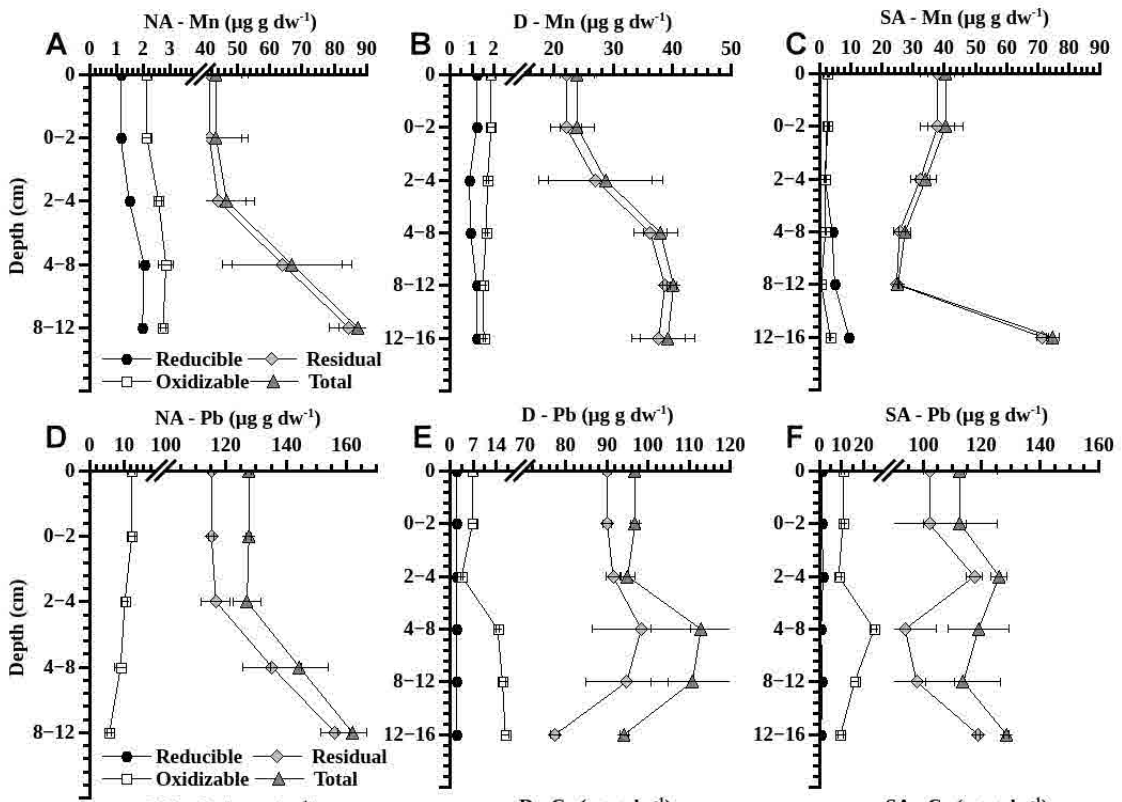

D - Pb $\left(\mu g g d w^{-1}\right)$
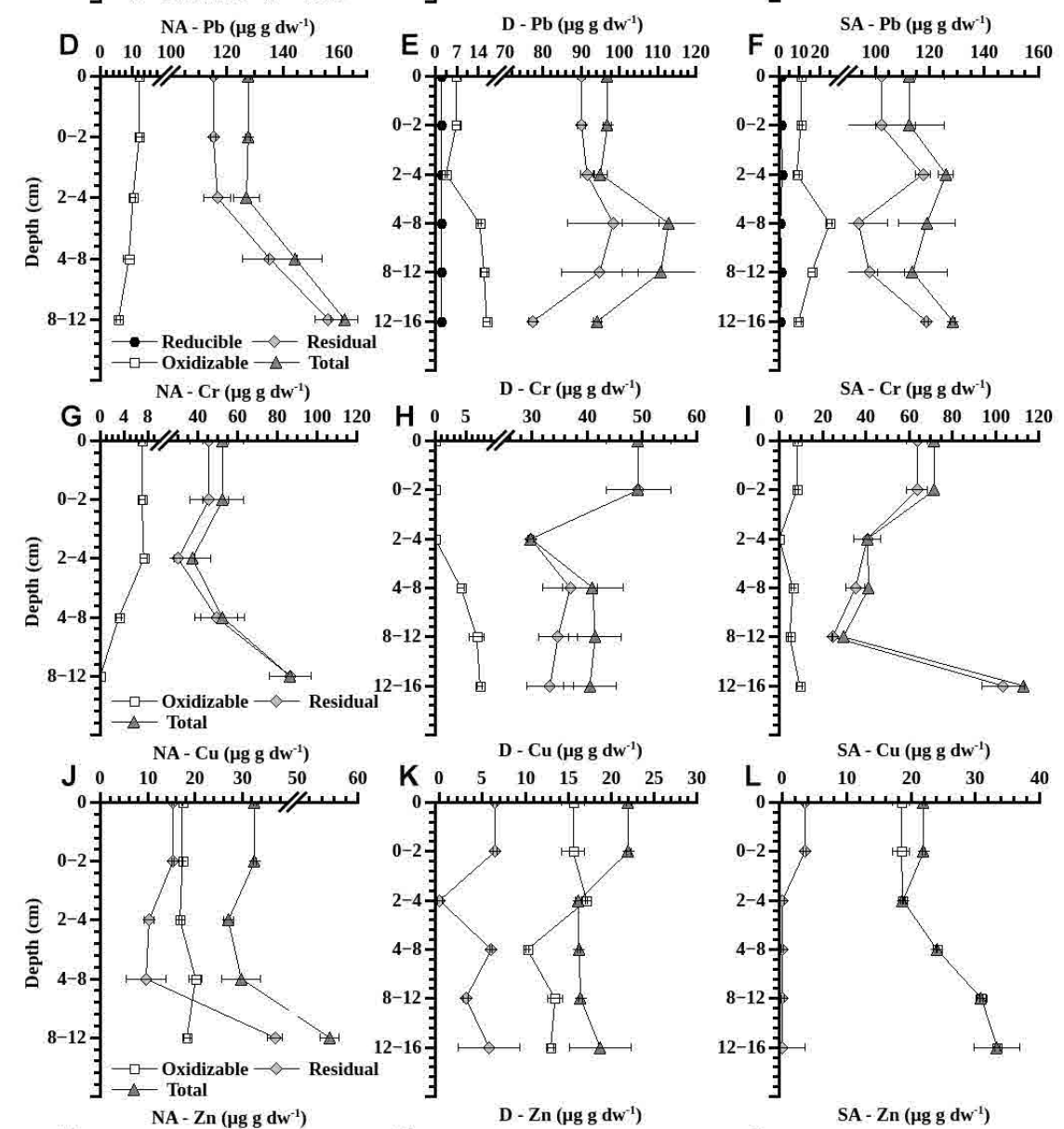

D - Cu ( $\left.\mu g g \mathrm{dw}^{-1}\right)$
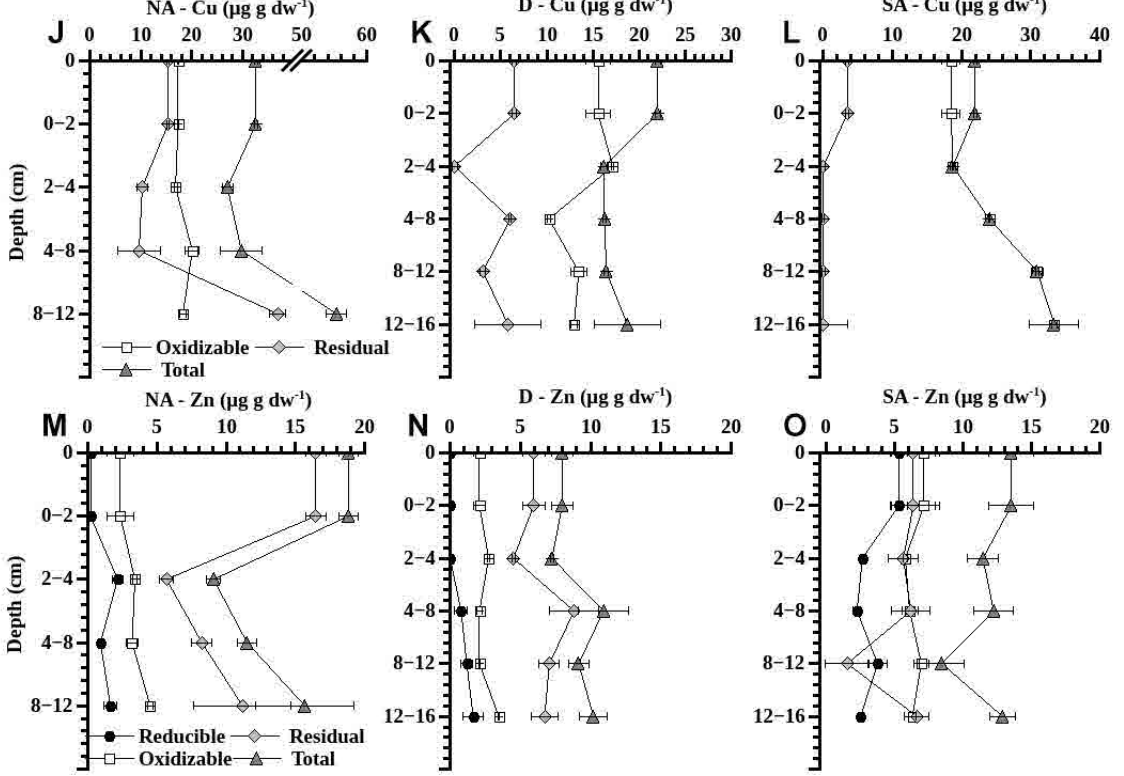

FIG. 4. Trace metal partitioning in reducible, oxidizable and residual phases at NA, D and SA sampling stations (expressed as $\mu \mathrm{g} g$ dw ${ }^{-1}$ of sediment; error bars indicate standard deviation with $n=3$ ). Total metal is the sum of all fractions. 
lower than the residual (F4) metal fraction between sampling stations $(\mathrm{p}<0,0001 ; 95 \%)$. The former is commonly associated to Mn oxides (Tessier et al., 1979) and it was higher at SA sampling station than at the remainder of the lake. The latter is usually associated with labile $\mathrm{OM}$ and pyrite. The residual fraction (F4), was comparable between SA and D sampling stations whereas at NA sampling station it was significantly higher $(p<0.045)$. Residual Mn increased towards the bottom sediments at NA and D sampling stations. At SA its content decreased from the first to four strata and it reached the maximum value at the fifth (Fig. 4C). The differences between strata were statistically significant $(\mathrm{p}<0.026)$ for all sites, although no statistical groups were formed.

\subsubsection{Lead}

Residual $\mathrm{Pb}$ was significantly higher than the other fractions ( $p<0.0001 ; 90 \%$ on average). Its total content ranged between $127-162 \mu \mathrm{g} \mathrm{g}^{-1}$ at NA sampling station, $97-112 \mu \mathrm{g} \mathrm{g}^{-1}$ at $\mathrm{D}$ sampling station and 112-128 $\mu \mathrm{g} \mathrm{g}^{-1}$ at SA sampling station (Fig 4D-F). With regard to $\mathrm{F} 4$ residual fraction, a tendency to rise towards the lower strata was observed exclusively at NA sampling station, with the third and fourth strata being significantly richer than the remainder of the profile $(\mathrm{p}=0.023)$. At $\mathrm{D}$ sampling station, lead content rose $5 \%$ between the first and second stratum and then decreased $10 \%$ towards the bottom whereas at SA sampling station the content oscillated between 90 and $110 \mu \mathrm{g} \mathrm{g}^{-1}$ (Fig. 4E-F). Reducible (F2) Pb was not detectable at NA sampling station while it was slightly over the LOD at D and SA sampling stations, being higher at D. Finally, oxidizable lead decreased significantly towards the bottom at NA sampling station from 17 to $7 \mu \mathrm{g} \mathrm{g}^{-1}(\mathrm{p}=0.023)$. The opposite trend was observed at D sampling station, where it rose downwards and at SA sampling station where it rose from 9 to $24 \mu \mathrm{g} \mathrm{g}^{-1}$ and then it decreases.

\subsubsection{Chromium}

Chromium, as well as $\mathrm{Mn}$ and $\mathrm{Pb}$, was significantly higher in F4 residual fraction $(91 \% ; p<0.0001)$. Its total content ranged between $37-84 \mu \mathrm{g} \mathrm{g}^{-1}$ at NA sampling station, 29-49 $\mu \mathrm{g} \mathrm{g}^{-1}$ at $\mathrm{D}$ and $29-113 \mu \mathrm{g} \mathrm{g}^{-1}$ at SA(Fig. 4G-I). Differences were significant between strata at each site but not among sites, and no trends were identified. Reducible Cr was below LOD and F3 (oxidizable) pattern was similar to that of $\mathrm{Pb}$. Moreover, at NA and SA sampling stations residual $\mathrm{Cr}$ was correlated with residual $\mathrm{Mn}(\mathrm{r}=0.88 ; \mathrm{p}<0.009)$, the similarity of the profiles can be seen in figure 4 (A-G and C-I). Finally, F4 residual fraction at D (Fig. $4 \mathrm{H}$ ) was nearly constant for the sub-superficial strata (below 4-8 cm).

\subsubsection{Copper}

Copper was detected only in F3 oxidizable and F4 residual fractions. Its content was significantly different $(\mathrm{p}<0.0001)$ at the three stations for both fractions. The order for the former fraction concentrations was: $\mathrm{SA}>\mathrm{NA}>\mathrm{D}$, while for the latter it was: $\mathrm{NA}>\mathrm{D}>\mathrm{SA}$. The total content ranged between $27-55 \mu \mathrm{g} \mathrm{g}^{-1}$ at NA, 16-22 $\mu \mathrm{g} \mathrm{g}^{-1}$ at D and 10-24 $\mu \mathrm{g} \mathrm{g}^{-1}$ at SA (Fig. 4J-L) and it was significantly higher at NA than at the remainder sites $(\mathrm{p}=0.024)$. In addition, total $\mathrm{Cu}$ rose downwards at NA and SA sampling stations while the opposite tendency was observed at D. Moreover, at SA and D sampling stations, $89 \%$ of $\mathrm{Cu}$ was detected in the oxidizable fraction whereas the differences at NA sampling station were not significant. At SA the residual metal was negligible, implying that most of the metal was distributed among the most reactive fractions.

\subsubsection{Zinc}

Zinc was the least abundant among the quantified metals. The differences in its distribution between chemical fractions or sampling sites (Fig. 4M-O) are not statistically significant. Its total content ranged between 7-18 $\mu \mathrm{g} \mathrm{g}^{-1}$. Traces of reducible metal were found at the three stations, being higher at SA. The richest fraction at NA and D sampling stations was the residual, whereas at SA sampling station the content of residual and oxidizable $\mathrm{Zn}$ was the same.

\subsubsection{Cadmium}

Cadmium concentration values were below the LOD and thus, will not be considered for quantitative analysis.

\subsection{AVS and SEM}

Acid volatile sulfide and cold-acid extractable $\mathrm{Fe}$ are shown in figure 5 (A-C). Although AVS will only be used for qualitative analysis, a strong and significant correlation was observed between the two variables $(r=0.988, p=0.001)$. AVS content was higher than $\mathrm{Fe}$ in most of the strata, consistent with the work of Koschorreck et al. (2003), and the average Fe content 

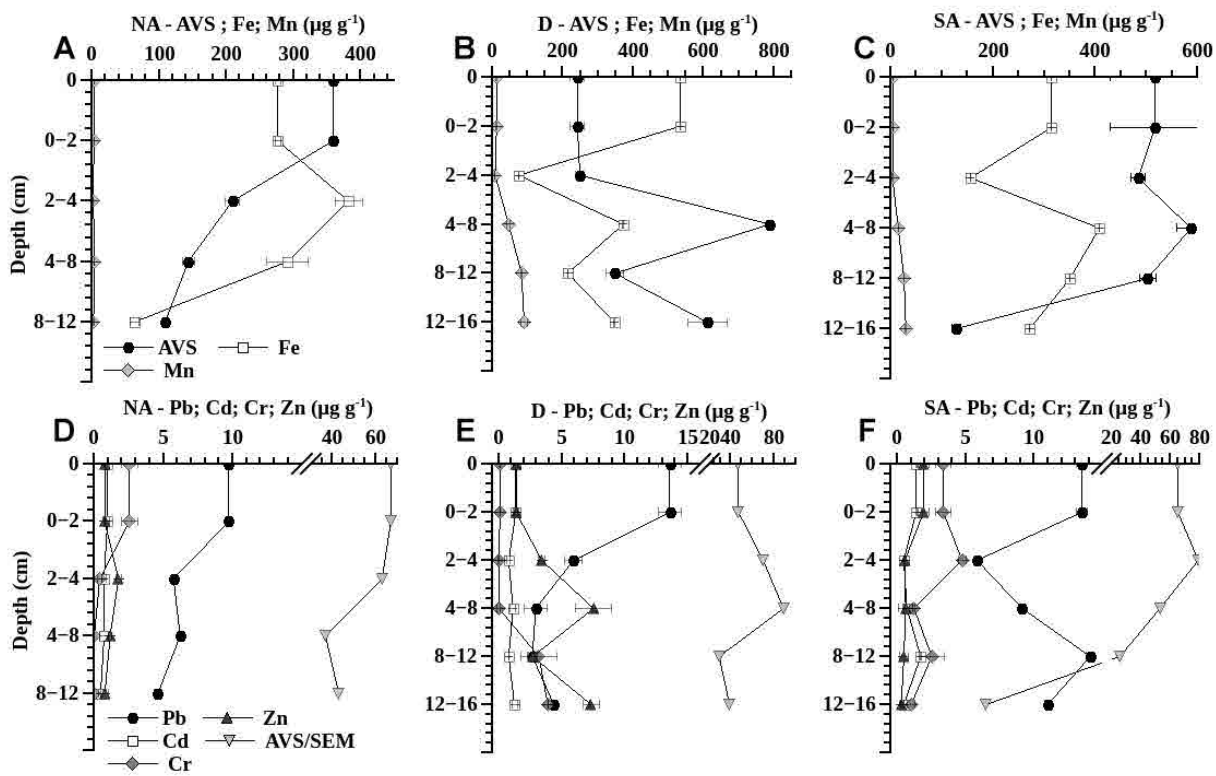

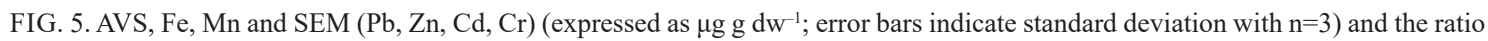
AVS/SEM.

was $264 \mu \mathrm{g} \mathrm{g}^{-1}$ at NA, $308 \mu \mathrm{g} \mathrm{g}^{-1}$ at D and $300 \mu \mathrm{g} \mathrm{g}^{-1}$ at SA, comparable with $457 \mu \mathrm{g} \mathrm{g}^{-1}$ reported by Cabrera et al. (2016) in the most labile F1+F2 fractions of SEP and significantly lower than the average total content of 5,190 $\mu \mathrm{g} \mathrm{g}^{-1}$ (Cabrera et al., 2016).

Overall trace metal content in the acid extracts were ten times lower than SEP values, the same trend observed for Fe. Zinc had high correlation with AVS $(r=0.931 ; p=0.020)$ at the three stations. Lead and $\mathrm{Cr}$ had significant association with sulfides exclusively at NA ( $\mathrm{r}=0.953 ; \mathrm{p}=0.045$ and $\mathrm{r}=0.977 ; \mathrm{p}=0.029$, respectively). Cadmium was slightly over the LOD and not considered for further analysis. Copper was detected exclusively at $\mathrm{D}$, being present only in the superficial stratum $\left.(0-2 \mathrm{~cm} ; 0.10 \mu \mathrm{mol} \mathrm{g})^{-1}\right)$, although it was expected because $\mathrm{CuS}$ is not solubilized in cold 1M HCl (Allen et al., 1991). Lastly, the ratio AVS/[SEM] was over 1.0 throughout all the sampled stations of the lake, thus indicating an excess of sulfide over trace metals.

\section{Discussion}

\subsection{Sequential extraction}

Metals associated with pyrite and $\mathrm{HCl}$ extracts (carbonates, sulfides, Fe-Mn oxides) have been previously characterized as reactive because they can dissolve, react to form other mineral phases or become incorporated by the benthic biota (HuertaDíaz et al., 2014). A number of single reagents and multiple combinations of them have been used to solubilize the mineral phases mentioned above, such as the SEP protocol employed in this work (Tessier et al., 1979). Therefore, extractable and reactive metal are considered synonyms henceforth.

With regard to SEP results, no trace metals were found in NaOAc supernatant (exchangeable and carbonates fraction), the fraction that represents the more readily available metals. Sediments with less than $1 \%$ of the total metal content in this fraction, such as Caviahue, are not to be considered toxic to the aquatic environment (Perin et al., 1985).

The metal content in the oxides of the reducible fraction (F2) was slightly above the limit of detection for $\mathrm{Mn}, \mathrm{Pb}, \mathrm{Zn}$ and not detectable for $\mathrm{Cu}$ and $\mathrm{Cr}$. Oxides were not expected to be a conspicuous fraction in Caviahue sediment due to the low $\mathrm{pH}$ Eh combination (for a more detailed discussion about iron cycling in this particular environment see Cabrera et al., 2016). Metal content in this fraction rose towards the lower strata, coincidently with the increase of $\mathrm{pH}$. 
On the contrary, in the oxidizable fraction (F3) all the metals were above LOD. Chromium, $\mathrm{Pb}$ and $\mathrm{Mn}$ average content in this fraction was lower than ten percent. On the other hand, $\mathrm{Ox}-\mathrm{Cu}$ accounted for $54 \%, 78 \%$ and $97 \%$ at NA, D and SA, respectively, of the total $\mathrm{Cu}$, while Oxidizable $\mathrm{Zn}$ was $27 \%$ at NA and $\mathrm{D}$, and $57 \%$ at SA (although it should be noted that the differences for the latter were found to be not significant). In addition, these two metals in this fraction were significantly correlated $(\mathrm{r}=0.73$; $\mathrm{p}=0.0029$ ) and richest in SA. A hypothesis to explain the association of these two metals in this lake is that both are intimately related with metalloproteins in eukaryotes (Dupont et al., 2010) and the benthic microbial biofilm on the lakes basin is composed mainly by the sedimented algae Keratococcus rhaphidioides. In this regard, other authors have thoroughly described the positive correlation of $\mathrm{Cu}$, $\mathrm{Pb}$ and $\mathrm{Zn}$ and the $\mathrm{OM}$ fraction (Nissenbaum and Swaine, 1976; Tessier et al., 1979; Rendina et al., 2001a; Rendina et al., 2001b; Lesven et al., 2010; Torres and Auleda, 2013). Moreover, Huerta-Díaz and Morse $(1990,1992)$ studied anoxic-sulfidic sediments such as Caviahue (although probably with higher $\mathrm{pH}$ ) and found that $\mathrm{Cu}$ and $\mathrm{Mn}$ had high tendency to be incorporated to pyrite, another possible phase in this fraction, in contrast with $\mathrm{Cr}$ and class "b" metals $\mathrm{Pb}$ and $\mathrm{Zn}$ which in Caviahue were almost exclusively associated with the residual fraction.

Should only the reactive facies be considered, $\mathrm{Cr}$ is described elsewhere chelated with the reducible and oxidizable fractions (Tokalioğlu et al., 2000; Cuong and Obbard, 2006; Rendina et al., 2006; among others) because it is found adsorbed to oxides and chelated with OM, both labile and recalcitrant. In this study, the former was negligible and the latter only found significantly related to labile $\mathrm{OM}$ (F3 fraction).

The residual fraction was richest in $\mathrm{Mn}, \mathrm{Cr}$ and $\mathrm{Pb}$, containing $90 \%$ of the extracted metals and poorest in $\mathrm{Cu}$. Moreover, strong and significant correlations were found between the three metals: 1) between $\mathrm{Mn}$ and $\mathrm{Cr}$ at the arms $(\mathrm{r}=0.78 ; \mathrm{p}=0.0011 ;$ Fig. 4A, $\mathrm{C}, \mathrm{G}, \mathrm{I}) ; 2$ ) between $\mathrm{Mn}$ and $\mathrm{Pb}(\mathrm{r}=0.83 ; \mathrm{p}=0.0002)$ at NA and D (Fig 4A, B, D, E) and 3) between Cr and $\mathrm{Pb}(\mathrm{r}=0.77 ; \mathrm{p}=0.0148$; Fig4D, G) specifically at NA. Chromium and lead are present in the lake water in a similar concentration range, however, $\mathrm{Mn}$ is one hundred times more concentrated. The same tendency was observed for $\mathrm{Cu}$ and $\mathrm{Zn}$ although to a lesser extent.

The Caviahue lake sediments consist mainly of volcanic ash and other volcanic particles. The strong acid used to obtain residual fraction would partially dissolve volcanic glasses, plagioclase, feldespar, piroxene and amphiboles. In this regard, Ruggieri et al. (2011) characterized the ashes from Copahue volcano eruption of the year 2000. After SEM and XRD studies, they found that glass is the main constituent of this ash. They leached the ashes with concentrated nitric acid and found similar contents of $\mathrm{Mn}, \mathrm{Cu}$ and $\mathrm{Zn}$ while the ashes were depleted in $\mathrm{Cr}$ and $\mathrm{Pb}$, contrasting with the values found in this work for the Caviahue lake sediments. In contrast, J. Varekamp, written communication, 2016, found that the ashes of the eruption of 2012 were richer in $\mathrm{Zn}$ and $\mathrm{Mn}$, with similar values of $\mathrm{Cu}$ and with deficit of $\mathrm{Cr}$ and $\mathrm{Pb}$ compared to the sediment analysis presented here. It was mentioned above that chromium and lead have high affinity for humic substances and therefore the precipitation of $\mathrm{Cr}$ and $\mathrm{Pb}$-humate complexes would enrich the sediments in these metals compared to the volcanic ash. Furthermore, Ruggieri et al. (2011) also found that $\mathrm{Zn}$ was one of the most mobile elements, therefore leaching of the ash particles at the low $\mathrm{pH}$ of the URA or the lake water ( $\mathrm{pH} \sim 1.0$ and 3.0, respectively) could explain its deficit with respect to 2012 ashes.

In addition, annual and inter-annual fluctuations in the concentrations of these metals in the Upper Agrio River and the lake, that were previously described by Varekamp (2008), Pedrozo et al. (2008a) and Cabrera et al. (2016), could also contribute to the irregularity of the vertical patterns and differences in metal content with respect to the volcanic ash. These variations mean different concentrations of precursors for hydrogenic precipitates.

In this study, no statistical correlation nor visible association was found between any of the metals (or the sum of them) and HA, although the content of the latter is 1,000 times higher. However, the interaction in situ cannot be ruled out because at the $\mathrm{pH}$ of the lake sediments $\mathrm{Pb}, \mathrm{Cr}$ and $\mathrm{Cu}$ were previously shown to have high binding parameters for the HA extracted from SA sampling station. On this subject, the differential affinity of the studied metals for humic/fulvic ligands by fluorescence titration has been established elsewhere (Christl et al., 2001; Plaza et al., 2006; Kostić et al., 2013). 


\subsection{AVS and SEM}

AVS was very high in Caviahue, equivalent to the content found in the sediments of the highly contaminated urban river Matanza-Riachuelo, in Buenos Aires, Argentina (Rendina et al., 2001a) and higher than most reports of contaminated sites. Caviahue lake has a very high content of dissolved sulfur species (Koschorreck et al., 2003) and therefore, high content of AVS was expected, although it is not impacted due to anthropic activities.

The extraction with cold $\mathrm{HCl}$ was performed to evaluate specifically the sediments potential toxicity (after Allen et al., 1993). The molar ratio AVS/SEM was over 1.0 in all stations and strata (values were between 5.4 and 88.5 ) thus indicating trace metal partitioning associated with this labile phase poses no risk to the algae and microorganisms in the water column and the sediments pore water (Allen et al., 1993). This result is in agreement with the low trace metal content in SEP most labile fractions, the exchangeable (F1) and reducible (F2).

Of all the metals detected in SEM extracts, $\mathrm{Fe}$ and $\mathrm{Zn}$ were shown to have high significant correlation at all sampling stations and thus, the presence of low amounts of $\mathrm{FeS}$ and $\mathrm{ZnS}$ species is suggested although $\mathrm{pH}$ is below 5.0 at the arms. Lead and $\mathrm{Cr}$ had likewise high correlation with AVS but only at NA sampling station. In addition, Mn was higher than the sum of the readily extractable fractions (F2+F3; Fig. 6) in the lower strata of $\mathrm{D}$ and SA sampling stations, which implies that some of the residual metal was recovered with cold acid, possibly due to leaching of the weakly bound metal to HA during this step. With the exception of $\mathrm{Zn}$ in two strata at D (Fig. 6), for the reminder of the metals the amount recovered in $(\mathrm{F} 2+\mathrm{F} 3)$ was always higher.

In addition, the average AVS/Fe molar ratios were calculated to evaluate the presence of different iron sulfide species. Only at NA the value was 1.7, close to greigite, while at D and SA it was of 2.5, thus indicating excess of sulfides, probably due to an excess of $\mathrm{H}_{2} \mathrm{~S}$ that was not purged with $\mathrm{N}_{2}$ during the 10 minutes at the beginning of the extraction. A ratio of 2.0 was not expected because the cold $\mathrm{HCl}$ does not dissolve pyrite, this method was designed to evaluate the presence of labile iron sulfide species.
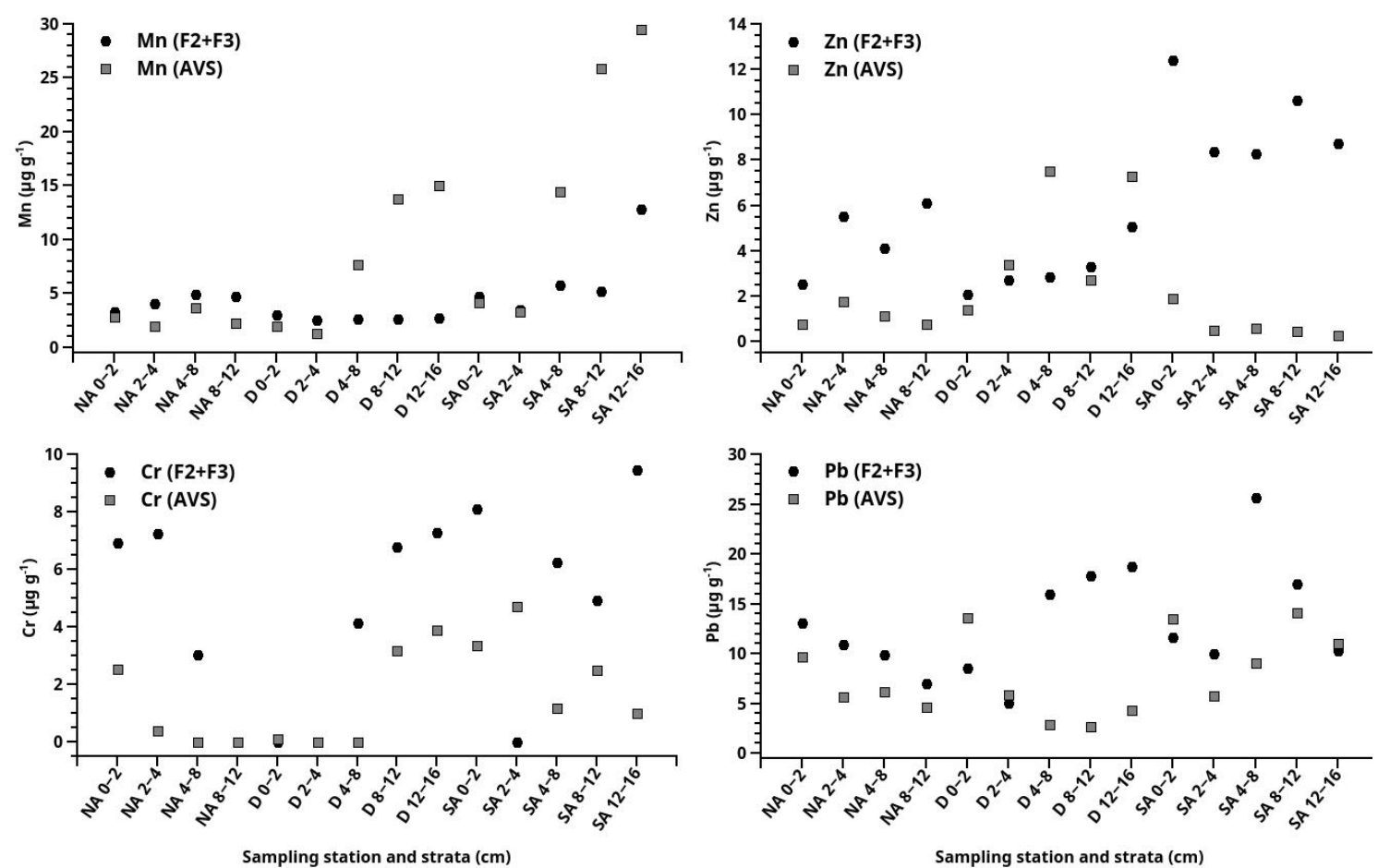

FIG. 6. Comparison between SEM metals (squares) and F2+F3 (reducible and oxidizable; dots) fractions of SEP. 


\subsection{Toxicity thresholds and mobility}

The observed influxes and lake concentrations for the time frame of the study were as follows: $\mathrm{Mn}>\mathrm{Zn}>\mathrm{Cr} \sim \mathrm{Pb}>\mathrm{Cu}$ (Varekamp, 2008, Cabrera et al., 2016; data not shown), albeit its content in the sediments was: $\mathrm{Cr}>\mathrm{Mn}>\mathrm{Pb}>\mathrm{Cu}>\mathrm{Zn}$. Compared to two international guidelines (Table 1) $\mathrm{Zn}$ was at least one order of magnitude below the lowest CCME (2001) threshold and is the least toxic of all. Chromium is within the margins of CCME (2001) values for NA, at D is mostly below and at SA is slightly above the upper limit, which overlaps with the ANZECC-ARMCANZ (2000) lower boundary. In addition, it is expected to be soluble as $\mathrm{Cr}^{+3}$ and $\mathrm{CrOH}^{+2}$ rather than as the hexavalent harmful forms (Richard and Bourg, 1991). Copper was below the lower value of the more conservative CCME (2001) for all the measurements with the exception of the lowest stratum of NA and SA. Finally, $\mathrm{Pb}$ was over the highest value of the Canadian guidelines and in between the New Zealand/Australian.

According with the mobility index $\left(\mathrm{MI}=\mathrm{M}_{\mathrm{R}} / \mathrm{M}_{\mathrm{T}}\right.$ with $\mathrm{M}_{\mathrm{R}}$ residual metal and $\mathrm{M}_{\mathrm{T}}$ total metal) proposed by Lesmes (1996) the most mobile metals are $\mathrm{Cu}$ and $\mathrm{Zn}$, these metals have higher proportion of the metals in the reducible and/or oxidizable fractions than $\mathrm{Cr}, \mathrm{Pb}$ and $\mathrm{Mn}$.

Caviahue lake sediments has higher concentrations of these metals (this work) than most unpolluted natural water bodies and comparable with moderately contaminated environments, rivers and lakes such as the Matanza-Riachuelo (Buenos Aires, Argentina; Magdaleno et al., 2001; Rendina et al., 2001a) a highly contaminated urban plain river; the Sancho reservoir (Torres and Auleda, 2013) or the Tinto and Odiel rivers (only for Cr; Galán et al., 2003) at the Iberian Pyrite Belt. Moreover, highly contaminated sediments after mining activity have concentrations of these metals up to $5 \mathrm{mg} \mathrm{g}^{-1}$ of dry sediment (Galán et al., 2003; Kirschbaum et al., 2012; among others). In Caviahue, the metals over the toxicity thresholds are mostly associated with the residual less labile fraction of the sediments, thus implying low risk for the hypolimnion and benthos.

In addition, the lake water $\mathrm{pH}$ has been rising since September 1998 to May 2018, with periods of temporal acidification due to an increase in the volcanic activity (e.g., years 2000, 2004 and 2013 after Varekamp 2008, 2015). It went from approximately 2.44 to 3.26 in the epilimnion and from 2.43 to 3.40 in the hypolimnion (G. Baffico, personal comunication, 2018). In this regard, the rocks from the coast have recently got coated by orange/red iron oxyhydroxides, similar to the schwertmannite found in the lower Rio Agrio bed where $\mathrm{pH}>3.0$ and iron precipitation occurs (Varekamp, 2015). Should $\mathrm{pH}$ continue to rise, the precipitation of iron can change the chemical characteristics of the lake. The amorphous iron oxyhydroxides such as schwertmannite or ferrihydrite may drag to the sediments adsorbed oxyanions of $\mathrm{P}, \mathrm{V}$ and As (as it occurs in the Agrio effluent; Varekamp, 2015). In addition, trace metals such as $\mathrm{Cu}, \mathrm{Pb}, \mathrm{Zn}, \mathrm{Cr}$ or $\mathrm{Cd}$ (among others) will be sorbed by the hydrous $\mathrm{Fe}$ oxides at $\mathrm{pH}$ values above 3.0 for cationic $\mathrm{Cr}$ and $\mathrm{Cu}$ (Davis and Leckie, 1978; Benjamin et al., 1982) and above 4.0 for the others (Dzombak and Morel, 1986), although the metals

TABLE 1. COMPARISON OF THE HEAVY METALS CONCENTRATIONS FOUND IN THE THREE SAMPLING STATIONS OF CAVIAHUE LAKE AND CCME (2001) AND ANZECC-ARMCANZ (2000) GUIDELINES FOR THE HM STUDIED.

\begin{tabular}{|c|c|c|c|c|c|c|c|}
\hline \multirow{3}{*}{$\begin{array}{c}\text { Guideline / } \\
\text { Metal }\end{array}$} & \multicolumn{7}{|c|}{ Metal concentration $\left(\mu \mathrm{g} \mathrm{g}^{-1}\right)$} \\
\hline & \multirow{2}{*}{$\begin{array}{l}\text { CCME } \\
\text { ISQG }\end{array}$} & \multicolumn{3}{|c|}{ ANZECC-ARMCANZ } & \multicolumn{3}{|c|}{ Caviahue (sampling stations) } \\
\hline & & PEL & ISQG-Low & ISQG-High & NA & D & SA \\
\hline $\mathrm{Zn}$ & 123 & 315 & 200 & 410 & & $7-18$ & \\
\hline $\mathrm{Cr}$ & 37 & 90 & 80 & 370 & $37-84$ & $29-49$ & $29-113$ \\
\hline $\mathrm{Cu}$ & 36 & 198 & 65 & 270 & $27-55$ & $16-22$ & $10-24$ \\
\hline $\mathrm{Pb}$ & 35 & 91 & 50 & 220 & $127-162$ & $97-112$ & $112-128$ \\
\hline
\end{tabular}

ISQG: Interim Sediment Quality Guidelines. PEL: Probable Effect Level. The values found for Zn in this work had no significant differences and therefore the average values were informed for all sampling stations. 
incorporated to the Fe oxides will increase with $\mathrm{pH}$ (Benjamin et al., 1982). Finally, this scenario will additionally imply a change in the $\mathrm{pH}$-buffer system, from Fe to $\mathrm{Al}$ (Geller et al., 1998; Pedrozo et al., 2008b; Cabrera et al., 2016).

\section{Conclusions}

The content of trace metals in the sediments of Lake Caviahue was comparable to other aquatic environments (acid or neutral) with low to moderate contamination levels for $\mathrm{Cu}, \mathrm{Cr}$ and $\mathrm{Pb}$. In contrast, $\mathrm{Zn}$ and $\mathrm{Cd}$ were below the toxicity threshold and limit of detection, respectively.

The content of trace metals in the exchangeable/ carbonates fraction (F1) of SEP extraction was below the limit of detection and SEM metal content was below the toxicity thresholds of two international sediment quality guidelines. Besides, the AVS/ SEM ratio, used often as a risk indicator, was higher than one, the threshold value. Moreover, after SEP extraction, $\mathrm{Cr}$ and $\mathrm{Pb}$, are not readily available and are the only metals above the toxicity thresholds. Copper was mostly associated with the oxidizable fraction (F3) and is not readily available either. Should $\mathrm{pH}$ continue to rise, the present concentration and partitioning of heavy metals in the sediments poses no risk to the aquatic biota.

Finally, no unique pattern was found that encompasses the distribution of all metals. However, $\mathrm{Cr}, \mathrm{Pb}$ and $\mathrm{Mn}$ were highly correlated and almost exclusively associated with the residual fraction (F4) of the SEP extraction, thus suggesting that these metals precipitate due to similar processes and/or co-variations of these metals in the volcano effluents.

\section{Acknowledgements}

Funding for this study was provided by Agencia Nacional de Promoción Científica y Tecnológica (ANPCyT Argentina; PICT 2008-1105; PICT 2012-1389), Consejo Nacional de Investigaciones Científicas y Técnicas (CONICET, Argentina; PIP 0013) and Universidad Nacional del Comahue (UNCo, Argentina; Program 04/ B166). The authors thank Dr. M. Díaz and Dr. G. Baffico (CONICET, Argentina) for the help during the sampling trips; MSE. A. Ferrari for his review and comments on the English language and A. Fantozzi for the help with the map. The authors also want to thank Professor Varekamp, the anonymous reviewer and Dr. W. Vivallo for their helpful comments.

\section{References}

Allen, H.E.; Fu, G.; Boothman, W.; Di Toro, D.M.; Mahony, J.D. 1991. Determination of acid volatile sulfide and selected simultaneously extractable metals in sediment. Office of Water Regulations and Standards, US Environmental Protection Agency: 1-22. Washington.

Allen, H.E.; Fu, G.; Deng, B. 1993. Analysis of acidvolatile sulfide (AVS) and simultaneously extracted metals (SEM) for the estimation of potential toxicity in aquatic sediments. Environmental Toxicology and Chemistry 12 (8): 1441-1453.

American Public Health Association (APHA). 1992. Standard methods for the examination of water and wastewaters, $16^{\text {th }}$ edition. American Public Health Association: $1250 \mathrm{p}$. USA.

ANZECC. 2000. Australian and New Zealand guidelines for fresh and marine water quality. Australian and New Zealand Environment and Conservation Council and Agriculture and Resource Management Council of Australia and New Zealand: 103 p. Canberra.

Bachmann, T.M.; Friese, K.; Zachmann, D.W. 2001. Redox and $\mathrm{pH}$ conditions in the water column and in the sediments of an acidic mining lake. Journal of Geochemical Exploration 73 (2): 75-86.

Baffico, G.D.; Diaz, M.M.; Wenzel, M.T.; Koschorreck, M.; Schimmele, M.; Neu, T.R. Pedrozo, F. 2004. Community structure and photosynthetic activity of epilithon from a highly acidic $(\mathrm{pH} \leq 2)$ mountain stream in Patagonia, Argentina. Extremophiles 8 (6): 463-473.

Beamud, S.G.; Diaz, M.M.; Baccalá, N.B.; Pedrozo, F.L. 2010. Analysis of patterns of vertical and temporal distribution of phytoplankton using multifactorial analysis: Acidic Lake Caviahue, Patagonia, Argentina. Limnologica-Ecology and Management of Inland Waters 40 (2): 140-147.

Benjamin, M.M.; Hayes, K.F.; Leckie, J.O. 1982. Removal of toxic metals from power-generation waste streams by adsorption and coprecipitation. Journal of the Water Pollution Control Federation 54 (11): 1472-1481.

Butler, I.B.; Rickard, D. 2000. Framboidal pyrite formation via the oxidation of iron (II) monosulfide by hydrogen sulphide. Geochimica et Cosmochimica Acta 64 (15): 2665-2672.

Cabrera, J.M.; Diaz, M.M.; Schultz, S.; Temporetti, P.; Pedrozo, F. 2016. Iron buffer system in the water column and partitioning in the sediments of the naturally acidic Lake Caviahue, Neuquén, Argentina. Journal of Volcanology and Geothermal Research 318: 19-26. 
Canadian Council of Ministers of the Environment. 2001. Canadian sediment quality guidelines for the protection of aquatic life: Summary tables. Updated. In Canadian environmental quality guidelines, 1999. Canadian Council of Ministers of the Environment, Canada.

Carter, M. 1993. Soil sampling and methods of analysis. Canadian Society of Soil Science. Lewis Pub.: 823 p. USA.

Christl, I.; Milne, C.J.; Kinniburgh, D.; Kretzschmar, R. 2001. Relating ion binding by fulvic and humic acids to chemical composition and molecular size. 2. Metal Binding. Environmental Science \& Technology 35: 2512-2517.

Cuong, D.T.; Obbard, J.P. 2006. Metal speciation in coastal marine sediments from Singapore using a modified BCR-sequential extraction procedure. Applied Geochemistry 21 (8): 1335-1346.

Davis, J.A.; Leckie, J.O. 1978. Effect of adsorbed complexing ligands on trace metal uptake by hydrous oxides. Environmental Science \& Technology 12 (12): 1309-1315.

Delpino, D.; Varekamp, J.C.; Bermudez, A. 1997. Influencia de un sistema volcanico activo sobre un lago de origen glacial: Lago Caviahue, Neuquen, Argentina. In Proceedings of $7^{\text {th }}$ International Conference on Lakes Conservation and Management: 1-4 p. Bariloche

Diaz, M.; Pedrozo, F.; Reynolds, C.; Temporetti, P. 2007. Chemical composition and the nitrogen-regulated trophic state of Patagonian lakes. Limnologica-Ecology and Management of Inland Waters 37 (1): 17-27.

Dillon, P.J.; Yan, N.D.; Harvey, H.H.; Schindler, D.W. 1984. Acidic deposition: effects on aquatic ecosystems. Critical Reviews in Environmental Science and Technology 13 (3): 167-194.

Dupont, C.L.; Butcher, A.; Valas, R.E.; Bourne, P.E. Caetano-Anollés, G. 2010. History of biological metal utilization inferred through phylogenomic analysis of protein structures. Proceedings of the National Academy of Sciences 107 (23): 10567-10572.

Dzombak, D.A.; Morel, F.M. 1986. Sorption of cadmium on hydrous ferric oxide at high sorbate/sorbent ratios: equilibrium, kinetics, and modeling. Journal of Colloid and Interface Science 112 (2): 588-598.

Friese, K.; Wendt-Potthoff, K.; Zachmann, D.W.; Fauville, A.; Mayer, B.; Veizer, J. 1998. Biogeochemistry of iron and sulfur in sediments of an acidic mining lake in Lusatia, Germany. Water, Air, and Soil Pollution 108 (3-4): 231-247.

Galán, E.; Gómez-Ariza, J.L.; González, I.; FernándezCaliani, J.C.; Morales, E.; Giráldez, I. 2003. Heavy metal partitioning in river sediments severely polluted by acid mine drainage in the Iberian Pyrite Belt. Applied Geochemistry 18 (3): 409-421.

Gammons, C.H.; Wood, S.A.; Pedrozo, F.; Varekamp, J.C.; Nelson, B.J.; Shope, C.L.; Baffico, G. 2005. Hydrogeochemistry and rare earth element behavior in a volcanically acidified watershed in Patagonia. Argentina. Chemical Geology 222 (3): 249-267.

Geller, W.; Klapper, H.; Schultze, M. 1998 Natural and anthropogenic sulfuric acidification of lakes. In Acidic mining lakes: acid mine drainage, limnology and reclamation (Geller, W.; Kappler, H.; Salomon, W.; editors). Springer: 435 p. Berlin.

Hübner, R.; Astin, K.B.; Herbert, R.J. 2009. Comparison of sediment quality guidelines (SQGs) for the assessment of metal contamination in marine and estuarine environments. Journal of Environmental Monitoring 11 (4): 713-722.

Huerta-Diaz, M.A.; Morse, J.W. 1990. A quantitative method for determination of trace metal concentrations in sedimentary pyrite. Marine Chemistry 29: 119-144.

Huerta-Diaz, M.A.; Morse, J.W. 1992. Pyritization of trace metals in anoxic marine sediments. Geochimica et Cosmochimica Acta 56 (7): 2681-2702.

Huerta-Diaz, M.A.; Muñoz-Barbosa, A.; Otero, X.L.; Valdivieso-Ojeda, J.; Amaro-Franco, E.C. 2014. High variability in geochemical partitioning of iron, manganese and harmful trace metals in sediments of the mining port of Santa Rosalia, Baja California Sur, Mexico. Journal of Geochemical Exploration 145: 51-63.

Kirschbaum, A.; Murray, J.; Arnosio, M.; Tonda, R.; Cacciabue, L. 2012. Pasivos ambientales mineros en el noroeste de Argentina: aspectos mineralógicos, geoquímicos y consecuencias ambientales. Revista Mexicana de Ciencias Geológicas 29 (1): 248-264.

Koschorreck, M.; Wendt-Potthoff, K.; Geller, W. 2003. Microbial sulfate reduction at low $\mathrm{pH}$ in sediments of an acidic lake in Argentina. Environmental science \& technology 37 (6): 1159-1162.

Kostić, I.S.; Anđelković, T.D.; Nikolić, R.S.; Cvetković, T.P.; Pavlović, D.D.; Bojić, A.L. 2013. Comparative study of binding strengths of heavy metals with humic acid. Hemijska industrija 67 (5): 773-779.

Kwong, Y.T.J.; Lawrence, J.R. 1998. Acid generation and metal immobilization in the vicinity of a naturally acidic lake in central Yukon Territory, Canada. In Acidic mining lakes: acid mine drainage, limnology and reclamation (Geller, W.; Kappler, H.; Salomon, W.; editors). Springer: 435 p. Berlin. 
Lesven, L.; Lourino-Cabana, B.; Billon, G.; Recourt, P.; Ouddane, B.; Mikkelsen, O.; Boughriet, A. 2010. On metal diagenesis in contaminated sediments of the Deûle river (northern France). Applied Geochemistry 25 (9): 1361-1373.

Löhr, A.J.; Sluik, R.; Olaveson, M.M.; Ivorra, N.; Van Gestel, C.A.; Van Straalen, N.M. 2006. Macroinvertebrate and algal communities in an extremely acidic river and the Kawah Ijen crater lake $(\mathrm{pH}<0.3)$, Indonesia. Archiv für Hydrobiologie 165 (1): 1-21.

Magdaleno, A.; Puig, A.; De Cabo, L.; Salinas, C.; Arreghini, S.; Korol, S.; Moretton, J. 2001. Water pollution in an urban Argentine river. Bulletin of environmental contamination and toxicology 67 (3): 0408-0415.

Nissenbaum, A.; Swaine, D.J. 1976. Organic matter-metal interactions in recent sediments: the role of humic substances. Geochimica et Cosmochimica Acta 40 (7): 809-816.

Pedrozo, F.; Kelly, L.; Diaz, M.; Temporetti, P.; Baffico, G.; Kringel, R.; Friese, K.; Mages, M.; Geller, W.; Woelfl, S. 2001. First results on the water chemistry, algae and trophic status of andean acidic lake system of volcanic origin in Patagonia (Lake Caviahue). Hydrobiologia 452: 129-137.

Pedrozo, F.; Temporetti, P.; Beamud, G.; Diaz, M. 2008a. Volcanic nutrient inputs and trophic state of Lake Caviahue. Patagonia. Argentina. Journal of Volcanology and Geothermal Research 178: 205-212.

Pedrozo, F.L.; Temporetti, P.; Beamud, G.; Draper, K. 2008b. Un lago andino-patagónico de $\mathrm{pH}$ variable: el Lago Caviahue. In Congreso Argentino de Limnología, No. 4, San Carlos de Bariloche.

Perin, G.; Craboledda, L.; Lucchese, M.; Cirillo, R.; Dotta, L.; Zanette, M.L.; Orio, A.A. 1985. Heavy metal speciation in the sediments of northern Adriatic Sea. A new approach for environmental toxicity determination. Heavy metals in the environment 2 (1): 454-456.

Plaza, C.; Brunetti, G.; Senesi, N.; Polo, A. 2006. Molecular and quantitative analysis of metal ion binding to humic acids from sewage sludge and sludge-amended soils by fluorescence spectroscopy. Environmental science and technology 40: 917-923.

Rendina, A.; Bargiela, M.; de Cabo, L.; Arreghini, S.; de Iorio, A.F. 2001a. Formas geoquímicas de metales pesados en sedimentos del Río Matanza y principales afluentes. Revista del Museo Argentino de Ciencias Naturales 3 (1) 33-39.

Rendina, A.; de Cabo, L.; Arreghini, S.; Bargiela, M.; de Iorio, A.F. 2001b. Geochemical distribution and mobility factors of $\mathrm{Zn}$ and $\mathrm{Cu}$ in sediments of the Reconquista River, Argentina. Revista Internacional de Contaminación Ambiental 17 (4): 187-192.

Rendina, A.; Barros, M.J.; De Lorio, A.F. 2006. Phytoavailability and solid-phase distribution of chromium in a soil amended with organic matter. Bulletin of environmental contamination and toxicology 76 (6): 1031-1037.

Richard, F.C.; Bourg, A.C. 1991. Aqueous geochemistry of chromium: a review. Water Research 25 (7): 807-816.

Stumm, W.; Morgan, S. 1996. Aquatic chemistry, Chemical equilibria and rates in natural waters. $2^{\text {nd }}$ edition, John Wiley \& Sons, Inc.: 1022 p. USA.

Temporetti, P.; Snodgrass, K.; Pedrozo, F. 2013. Dynamics of phosphorus in sediments of a naturally acidic lake. International Journal of Sediment Research 28 (1): 90-102.

Tessier, A.; Campbell, P.G.; Bisson, M. 1979. Sequential extraction procedure for the speciation of particulate trace metals. Analytical chemistry 51 (7): 844-851.

Tokalioğlu, Ş.; Kartal, Ş.; Elci, L. 2000. Determination of heavy metals and their speciation in lake sediments by flame atomic absorption spectrometry after a four-stage sequential extraction procedure. Analytica Chimica Acta 413 (1): 33-40.

Torres, E.; Auleda, M. 2013. A sequential extraction procedure for sediments affected by acid mine drainage. Journal of Geochemical Exploration 128: 35-41.

Varekamp, J.C. 2008. The volcanic acidification of glacial Lake Caviahue, Province of Neuquen, Argentina. Journal of Volcanology and Geothermal Research 178 (2): 184-196.

Varekamp, J.C. 2015. The Chemical Composition and Evolution of Volcanic Lakes. In Volcanic Lakes. Advances in Volcanology (Rouwet, D.; Christenson, B.; Tassi, F.; Vandemeulebrouck, J.; editors). Springer, Berlin, Heidelberg.

Wendt-Potthoff, K.; Koschorreck, M. 2002. Functional groups and activities of bacteria in a highly acidic volcanic mountain stream and lake in Patagonia. Argentina. Microbial ecology 43 (1): 92-106. 